\title{
An Ethnographic Exploration of Food and The City
}

\section{MARC C.A. WEGERIF}

Marc Wegerif is a post-doctoral fellow researching food and land rights with the Human Economy Programme, University of Pretoria. His doctorate focused on the food system feeding the city of Dar es Salaam. He has worked on development and human rights issues for 30 years. His email is marc.wegerif@ up.ac.za.

While living in Dar es Salaam, I became fascinated by how the food I was eating had been produced and distributed. I lived in three different houses during my time there and within a hundred metres of each there was a duka (shop). I observed bicycles delivering eggs, bread and more to these dukas. Walking further from home, I bought fresh vegetables and other foods in markets where traders sat next to each other selling the same products at the same prices and assisting each other in other ways, even though from an orthodox economics perspective they should have been competing for customers. Statistics showed that most basic foods feeding the city, and Tanzania as a whole, were produced by wakulima (farmers) with an average of just 1.3 hectares each. How this food system worked became the focus of my PhD research (Wegerif, 2017).

The background to this interest includes that I am from South Africa where, as in many countries, most of the population is urban and large corporate owned supermarket groups dominate food retailing. In such environments it becomes hard to imagine feeding cities without these companies, yet we are increasingly aware of the negative social and ecological impacts of the corporate agro-industrial food regime (Rieff, 2015; Wiskerke and Viljeon, 2012; Lang, 2010; Patel, 2007).

\section{Using ethnography without prior assumptions}

With a broad question in my mind - how to sustainably feed large cities in a way that is beneficial to food producers - I set about exploring the main food system feeding Dar es Salaam with its fast-growing population of over 4.6 million people (National Bureau of Statistics, 2013). My four years of research took an actor-orientated ethnographic approach, starting with a diverse range of eaters in the city and following the food (Cook, 2006; Cook, 2004) to the retailers, processors, transporters, and traders until I found myself in the fields of the wakulima. Essential for revealing the ordering principles of their food system was a focus on people's everyday practices; not starting with NGO, state, or corporate interventions. I also deliberately avoided assumptions of a linear modernization path of 'development' (Arce and Long, 2000) and the use of categories, such as 'informal' and 'consumer'.

Spending time traveling and sharing meals with eaters and other actors in the food system, I gathered data on their food practices and perspectives. I observed how they made their economic lives and responded to and reshaped the systemic and external pressures and opportunities they faced (Hart, 2015; Long, 2001).

Following the Food

The foods I focussed on, due to their importance and variety, were maize, rice, potatoes, eggs, milk and green vegetables. The heavy staple foods came from a wide geographic area across Tanzania (Wegerif and Wiskerke, 2017). The eggs, milk and green vegetables involved urban and peri-urban production, but also trucking into the city from hundreds of kilometres away (Wegerif, 2014). With all the foods I found similar patterns of traders buying even small 
quantities for cash at the 'farm-gate' whether in remote villages or from urban producers. Some food went through regional and wholesale markets, in other cases it went directly to Dar es Salaam and with urban production sometimes straight from the field or garden to urban eaters. Dalalis (agents working on commission) and traders played an essential role in facilitating links between actors, arranging transport from numerous often small-scale transport providers, and bulking food for efficient transportation at key nodes. There were no written contracts; people familiar with each other made deals and mostly paid in cash with witnesses observing. The primary production was by wakulima often using low external input farming practices in a default agro-ecological approach that has the potential for sustainable production despite serious challenges from climate change and pressures on land and natural resources. Production was not static; as the city grew by 2 million people in the 15 years to 2016, food supplies kept up. For example, rice production in Tanzania doubled in that period and potato production increased 2.5 times, this still in the hands of small-scale wakulima (Wegerif and Wiskerke, 2017; National Bureau of Statistics, 2012; FAOSTAT, 2016).

Important sources of food for urban eaters were dukas, people's markets, door to door deliveries, gifts from urban and rural producers, direct procurement from urban farmers, street-food vendors, and speciality shops such as those focussed on selling grains. The main factors contributing to food accessibility for the majority of residents, who lived on low and unreliable incomes, were: low prices; availability in flexible quantities; proximity to place of residence; long opening hours; availability of credit; sharing in family and friend networks, especially for children; and having a source of income in order to be able to purchase (Wegerif, 2014). Supermarkets performed poorly on all the above-mentioned factors and thus were not used by the majority of eaters. Major supermarket groups, such as Shoprite, Nakumat, and Uchumi all struggled in Tanzania and closed their operations there during the years of my research. The handful of supermarkets remaining were used by expatriates and elite Tanzanians.

\section{Meeting some actors involved}

For years I interacted almost daily with Mangi who owns and runs a duka near where I lived. Mangi, the Chagga word for chief, is widely used to refer to shopkeepers. In this case Mangi is actually twin brothers and they are, like many shopkeepers in Dar es Salaam, ethnically Chagga. The brothers are from Moshi and return there annually to visit relatives and plant maize on two hectares of family land. They had both worked in someone else's shop for years, saving money and learning the business until they were ready to start their own $d u k a$.

As well as buying food and household goods from Mangi's duka, it was from them, or neighbours I met at their shop, that I received the local news. Mangi knows everyone in the street and attends weddings, funerals and other events in the area. Like other $d u k a$ owners, they open from around 7am to 10pm daily, selling flexible quantities, for example weighing out a quarter kilo of rice, and when regular customers are short of cash they give items on 
credit. The credit assists people on unreliable incomes and creates customer loyalty as it is linked to being known by Mangi and buying in the $d u k a$ when you have money.

A 15-minute walk from Mangi's duka is the Mikoroshoni market with 90 registered food traders. On one of many days there, I sat on a rough wooden bench next to Stella, although she stood most of the time behind the table where the green vegetables she sells were laid out. Stella was busy cutting spinach for a customer as she chats to them in her home language of Hehe, as opposed to the usual Swahili. When there are no customers, Stella talks with neighbouring stall holders. This afternoon, the man who sells the same green vegetables from a stall next to her is away. Stella keeps an eye on his stock and sells for him when his customers come to buy. On other days he or another trader returns the favour in mutual support that is particularly important for Stella who is a single mother. She doesn't need to shut her stall or employ an assistant when she takes a child to the doctor or has other tasks, her fellow market traders help out. She has similar relationships where she lives; she tells me that her children look after themselves after school, but her neighbour will call if there is a problem.

Stella doesn't try to compete on price, she explains that this could lead to reduced profits for all of them. She says customers come to her because they know her. Although later in the afternoon she tells me, in close to a whisper, that she sometimes cuts up or grinds vegetables for regular customers for free. Competing on price is not an acceptable practice, but discounting a value adding service can be done discretely and, although frowned on, is within acceptable limits of competition.

Stella has been in Dar es Salaam for 13 years but returned to her home village in Iringa Region for the birth of each of her three children. Nine years ago, a neighbour helped her get the stall from a woman who was leaving the market. That woman was one of the original founders who pooled their resources to build the market structure. Another trader in the market told Stella about the business and showed her where she could buy stock.

At 3am one morning I joined Stella and 15 other Mikoroshoni market traders on their daily minibus ride to the Ilalla market. There, in the crowded streets, trucks from up to $400 \mathrm{kms}$ away and wakulima from nearby, including urban farmers, bring and sell fresh produce. Stella bought her stock from traders she was familiar with and then joined with others to jointly hire a three-wheeled motorised transport to get their stock to Mikoroshoni. Soon after 6am she was at her stall washing and setting out her green vegetables.

I arrived by bicycle outside the maize mill and found Enjo sitting with five other women sembe (maizemeal) traders in the shade of a tree next to the open ground where maize bran is spread on tarpaulins to dry. The maize bran, left after milling, gets sold for animal feed, mostly for chickens that are kept across the city. The mill, one of thousands in Dar es Salaam, is owned by a local businessman and used continually by Enjo and eight other sembe traders who pay per kilo for the milling service. Sitting together under the tree is social, but also where information is shared and business arrangements are made, such as collaborating to share a truck load of maize when they lack the capital to fill a truck on their own. Enjo and her sister, 
both used to be waitresses in a bar, and their brother, a part-time gym instructor, started their own sembe brand. They buy maize, grind and package it and distribute to shops using hired vehicles. They got into the business after another sembe trader told them about the business and the profits they could make. Unlike many other parts of the food system, the sembe trade involves brands, printed on the sacks, and more overt price competition. Enjo tells me she wants her brand to be known for consistent quality. Visiting shops with her brother reveals how his friendship with shop owners is also a reason they buy Enjo sembe.

\section{How it works}

The vignettes above give a glimpse into the operations of actors in the food system. They share many characteristics and a common mode of ordering with the majority of actors from the wakulima to retailers and eaters; they eat similar foods, cook in the same ways and live in comparable conditions. They combine high levels of autonomy and individual control (e.g. my shop, my farm) with high levels of collaboration with people they are at least familiar with and who operate from common cultural repertoires. In their daily practices they are asking, and to some extent answering, the core question Durkheim (1984: xxx) asked of how it is "that the individual, whilst becoming more autonomous, depends ever more closely upon society?"

Time at abattoirs and meat markets revealed in graphic ways how every stage in the slaughter, cleaning and selling, and every part of the animal becomes an economic activity for another person, and the viability of each person's enterprise depends on the functioning of the others. Many chickens are reared by small-scale urban and peri-urban producers, chicken traders buy and sell, butchers who are all individual operators collaborate in teams sharing slaughter areas and hot water for the cleaning. When the chicken buyer doesn't want the heads and feet these are a business for street food vendors who cook and sell them. The chicken droppings get sold as manure to urban farmers who produce vegetables that are often sold in the same market as the chickens.

The apprenticeship type opportunities, with experienced relatives or friends, are essential for the reproduction of the food system. Through this process people learn the social norms underpinning the relations that keep the system functioning as well as activity specific skills. Wakulima learn in the fields of their parents, other relatives or neighbours. Duka owners start as shop assistants learning the business while saving money to open their own stores. A rice trader I met over 800 kilometres from Dar es Salaam told me, "it is essential when you start to get someone who can lead you, for the first journey and the second journey, then you can start to be independent... I was with a friend... I just asked to go with them, they explained this grain you can sell for this price, and this grain for this price" (Wegerif, 2017: 229). This seems strange as people are helping create competitors, but it makes sense when one realises that these will be future collaborators in the sector and they are contributing to sustaining a system that they benefit from and perhaps their children will be part of. This practice also incentivises workers to be loyal to employers who will help them start their own businesses in the future. 
Traders sit together in markets, travel together, share information, help with social activities like contributing to funeral costs, and share transport. They operate with an ongoing tension between competing with and assisting each other. As one maize trader put it: "we are competitors and friends, we apologize when beating someone in a business deal and also help each other" (Wegerif and Hebinck, 2016: 6). At times actors try to gain an advantage over their collaborator/competitors, but reputation and trust are essential to how people work together, those who step outside the accepted limits are quickly ostracized and excluded from collaborations that they depend on.

I use the term symbiotic as the relations involved include but go beyond the directly reciprocal and the structured arrangements that collaborative implies. The actors operate within established norms that they rarely question and through which they sustain a system they all benefit from. It includes a variety of relations from more to less mutually beneficial, but does not tolerate predatory behaviour. To compete and make money is fine, but within limits; one of the most common criticisms I heard made about fellow actors was that they "love money a lot". An element of the system is comparable to academics reviewing journal articles for no pay. They are sometimes a little irritated by it, especially if the articles are bad, but they know others will review their work and that this keeps the production of credible academic work going.

In addition to social benefits, the resilience of the symbiotic food system can be seen in its economic competitiveness based on four main advantages: 1) No management overheads, despite being a complex multi-functional system; 2) No extraction of profit for absent shareholders, rather surpluses support actors in reproduction and get reinvested into the operations; 3) Owner run enterprises and involvement of family and apprentice labour keeps costs low and loyalty high; and 4) Efficient utilisation of limited capital inputs through key equipment being owned by separate actors serving many others.

Why does it work?

Despite the dominant neo-liberal economic views of today, it has long been known that market transactions and our economies do not only involve people maximising utility and their returns at the expense of others, but are in fact embedded in social relations informed by wider norms and values (Polanyi, 1957; Granovetter, 1985). Research on effective common pool resource management and human behaviour has shown that people are able to share limited resources and work with each other for the common good in polycentric organisation. We can do this, under the right circumstances, in part because most of us value characteristics such as trustworthiness and fairness, over greed and selfishness. It has been argued that through evolution and the transfer of cultural norms we are conditioned to have empathy and to reciprocate (Zak, 2011; Ostrom, 2010; Ostrom, 1990; Mauss, 1990). Most of us understand these values operating in family and clan groups, but I found them reaching far beyond those circles to become core ordering principles for food production and distribution across the country. The particular circumstances that enable this are explained in brief below. 
Tanzania was colonised, but it was not widely settled by the colonisers in the way that, for example, South Africa was. Thus, colonial agriculture and industry were not deeply entrenched and land dispossessions, while they occurred, did not displace the majority of Tanzanian's from their land. Indigenous 'peasant' production and food systems were able to survive and to some extent evolve and thrive, despite colonial and post-independence limitations on African farmers and traders (Hydén, 1980). In the first decades of independence the Tanzanian state preached "Socialism and Self Reliance" (TANU, 1967) and limited both the influx of foreign capital and the emergence of national commercial elites, although a bureaucratic elite exerted a strong influence (Shivji, 1976). A series of state interventions undermined Asian traders who had been favoured by the colonial powers and had dominated food trading (Bryceson, 1993; Shivji, 1976). Bryceson (1993) argues that policy uncertainties prevented Arab and Asian transporters getting into staple food trading, while the lack of capital amongst African traders prevented them getting into transporting. Thus vertical integration and further concentration of control and capital did not take place in the food and agricultural sector. With liberalisation in the mid-1980s, small-scale African traders, who had continued to exist despite being marginalized as 'black-market' or 'parallel economy' operators, came to the fore along with the small-scale wakulima. Formalised cooperatives gained a bad reputation due to misguided state interventions, rent seeking and inefficiency, but traders and farmers adopted their own collaborative approaches and dalalis often facilitated solutions, such as the joint use of vehicles and milling machines, to overcome capital limitations. These approaches kept financial barriers to entry low, while requiring one to maintain good social relations in order to be accepted within these collaborative solutions.

People found solutions to fit their particular socio-material circumstances that were rooted in the practices of wakulima who value their autonomy and combine that with mutual assistance and a shared social life in the village. Many food traders, even in the city, are or were farmers and maintain close links with rural and farming life. The similar scales of operation with limited access to capital that actors have in all parts of the symbiotic food system, and relative equity amongst them, is also fundamental to facilitating their interdependent relations. Even the larger rice and maize mill owners still depend on small-scale wakulima and traders using their facilities to finance and keep them going.

Government policy also plays a role. The nation building project, which among other things promoted a common language (Swahili), undoubtedly helped facilitate people extending relations across geographic and ethnic divides. Tariffs and other limitations on the importation of certain foods provides protection from the vagaries of international markets. Town planning and bi-laws have not always been consistent, but have supported urban agriculture, recognised market places and allowed space to open dukas in streets across the city.

Once established such ways of working have sustained due to their competitiveness, as explained above, and sanctions, such as ostracization if people take competition too far. 
While Tanzania has particular circumstances, such modes of ordering exist elsewhere, get reinforced in practice and can be taught to people from different backgrounds (Van der Ploeg et al., 2016; Zak, 2011; Ostrom, 1990). Research has even found white South Africans, despite the apartheid history, joining with and learning from their black neighbors how to survive in "networks of reciprocity and mutuality" (Sharp and van Wyk, 2015).

Feeding the city into the future.

My main conclusion is that a symbiotic food system is feeding the overwhelming majority of Dar es Salaam residents. It is based on a multitude of small-scale and interdependent actors who together produce food and get it to urban eaters at a city feeding scale without any large vertically or horizontally integrated corporate structures. This emerged from a particular history and is enabled by at least familiarity between actors with common cultural repertoires who are in relatively equitable positions of wealth and power when compared to actors in corporate controlled food regimes. The system involves diverse collaborations, even amongst competitors, and it expands in response to opportunity through replication, rather than through the scaling up that development agencies tend to focus on. This food system is not perfect, but it is working, has considerable social and environmental advantages, and should be learnt from and built on.

\section{References:}

Arce A and Long N. (2000) Reconfiguring modernity and development from an anthropological perspective. In: Arce A and Long N (eds) Anthropology, Development and Modernities. London and New York: Routledge.

Bryceson DF. (1993) Liberalizing Tanzania's Food Trade, London, Portsmouth (NH), Dar es Salaam: UNRISD in Association with James Currey, Heinemann and Mkuki na Nyota.

Cook I. (2004) Follow the Thing: Papaya. Antipode 36: 642-664.

Cook I. (2006) Geographies of food: following. Progress in Human Geography 30: 655-666.

Durkheim E. (1984) The Division of Labour in Society, London, UK: Macmillan.

FAOSTAT. (2016) Food and agriculture data. Available at:

http://fenix.fao.org/faostat/beta/en/\#home. 
Granovetter M. (1985) Economic action and social structure: The problem of embeddedness. American Journal of Sociology: 481-510.

Hart K. (2015) Human Economy: The Revolutionary Struggle for Happiness. In: Hart K (ed) Economy for and Against Democracy. New York and Oxford: Berghan Books, 201-220.

Hydén G. (1980) Beyond Ujamaa in Tanzania: underdevelopment and an uncaptured peasantry, Berkeley and Los Angeles, CA, USA: Univ of California Press.

Lang T. (2010) Crisis? What Crisis? The Normality of the Current Food Crisis. Journal of Agrarian Change 10: 87-97.

Long N. (2001) Development sociology: actor perspectives, London, UK: Routledge.

Mauss M. (1990) The Gift, London and New York: Routledge.

National Bureau of Statistics. (2012) Volume II: Crop Sector - National Report. Dar es Salaam, Tanzania: Government of the United Republic of Tanzania.

National Bureau of Statistics. (2013) 2012 Population and Housing Census. Dar es Salaam: National Bureau of Statistics, Ministry of Finance.

Ostrom E. (1990) Governing the Commons: The Evolution of Institutions for Collective Action, New York: Cambridge University Press.

Ostrom E. (2010) Beyond Markets and States: Polycentric Governance of Complex Economic Systems. American Economic Review 100: 408-444.

Patel R. (2007) Stuffed \& starved: Black Inc.

Polanyi K. (1957) The great transformation: the political and economic origins of our time., Boston: Beacon Press. 
Rieff D. (2015) The Reproach of Hunger: Food, Justice, and Money in the Twenty-first Century, New York, USA: Simon and Schuster Paperbacks.

Sharp J and van Wyk S. (2015) Beyond Markets: White Workers in Pretoria. In: Hart K (ed) Economy for and Against Democracy. New York and Oxford: Berghan Books, 120-136.

Shivji IG. (1976) Class Struggles in Tanzania, London: Heinemann.

TANU. (1967) The Arusha Declaration: Socialism and Self-Reliance. Reprint by Mwalimu Nyerere Professorial Chair in Pand African Studies ed. Dar es Salaam, Tanzania: Tanganyika African National Union (TANU).

Van der Ploeg JD, Huifang W and Congzhi H. (2016) Markets. In: Van der Ploeg JD and Jingzhong Y (eds) China's Peasant Agriculture and Rural Society: Changing paradigms of farming. Routledge: London, UK.

Wegerif MC. (2017) Feeding Dar es Salaam: a symbiotic food system perspective, Wageningen, Netherlands: Wageningen University.

Wegerif MC and Wiskerke JS. (2017) Exploring the Staple Foodscape of Dar es Salaam. Sustainability 9: 1081.

Wegerif MCA. (2014) Exploring Sustainable Urban Food Provisioning: The Case of Eggs in Dar es Salaam. Sustainability 6: 3747-3779.

Wegerif MCA and Hebinck P. (2016) The Symbiotic Food System: An 'Alternative'Agri-Food System Already Working at Scale. Agriculture 6: 40.

Wiskerke JSC and Viljeon A. (2012) Sustainable urban food provisioning: challenges for scientists, policy makers, planners and designers. In: Viljoen A and Wiskerke JSC (eds) Sustainable food planning: evolving theory and practice. Wageningen: Wageningen Academic Publishers, 19-35. 
Zak PJ. (2011) Moral markets. Journal of Economic Behavior E Organization 77: 212-233. 
Fig. 1. Bread delivery at a duka (shop), a social space and source of food in the neighbourhood.

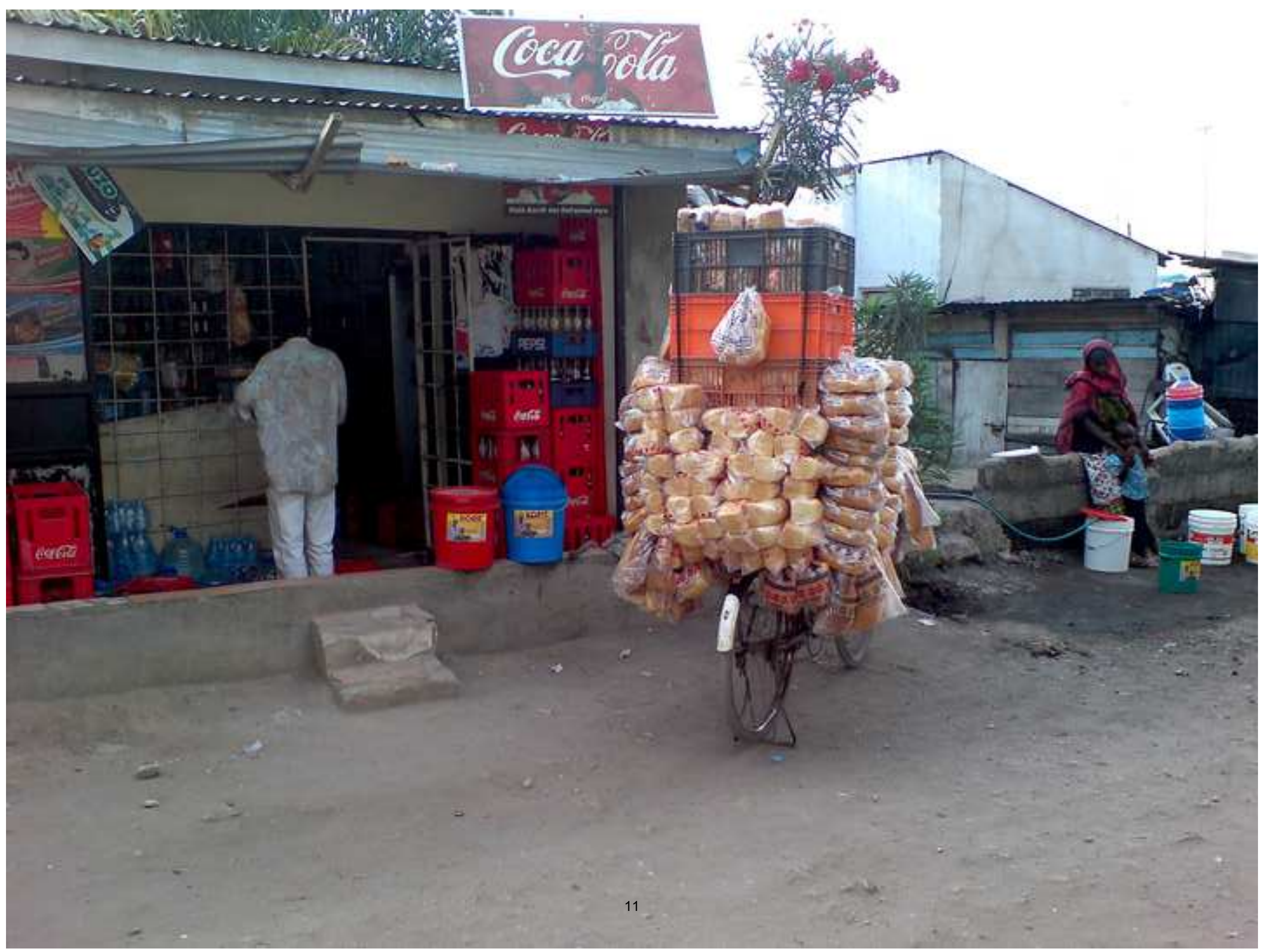


Fig. 2. A group of homeless youth cook and eat together on a street in Dar es Salaam.

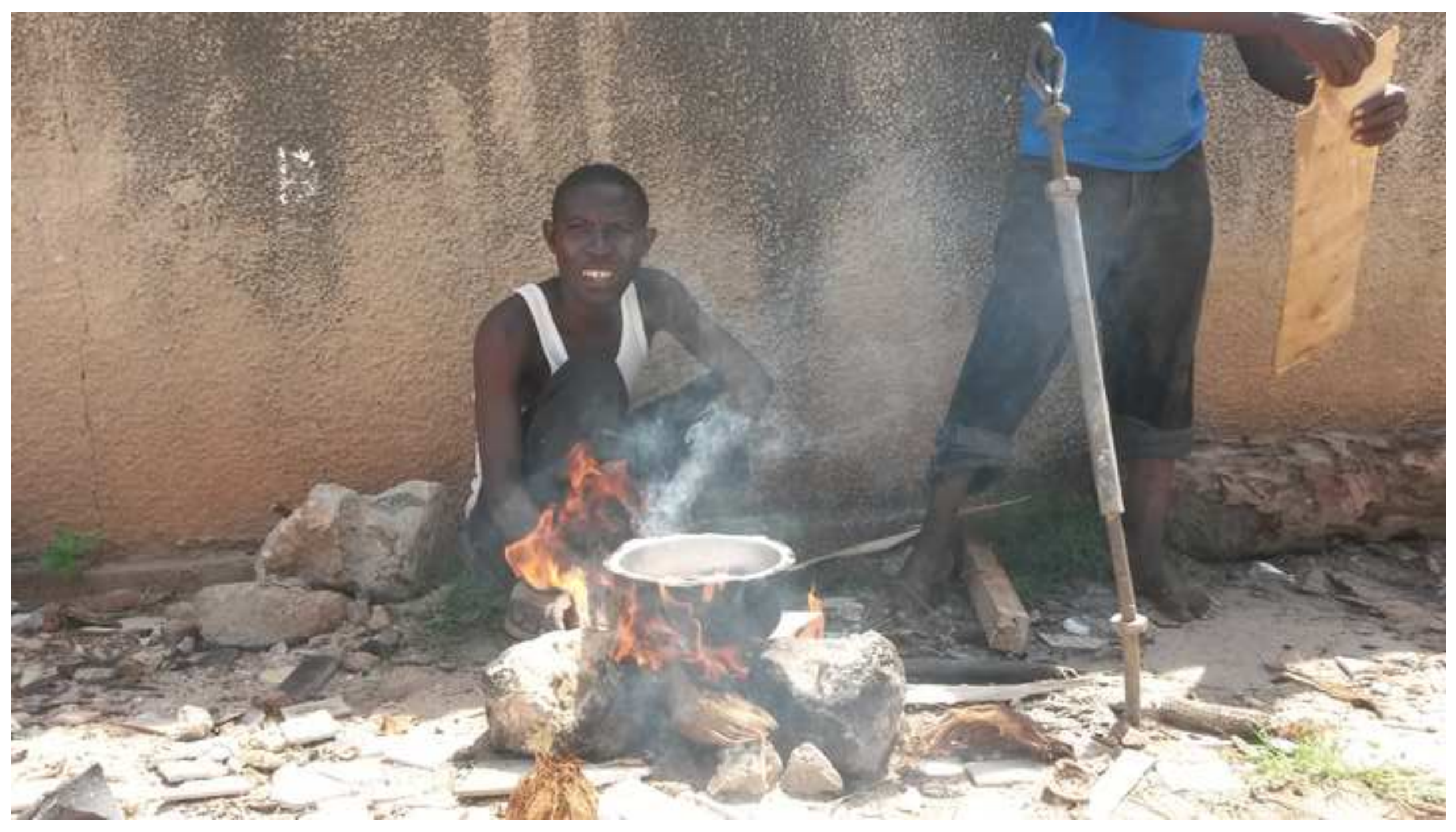


Fig. 3. Urban horticulture in Dar es Salaam.

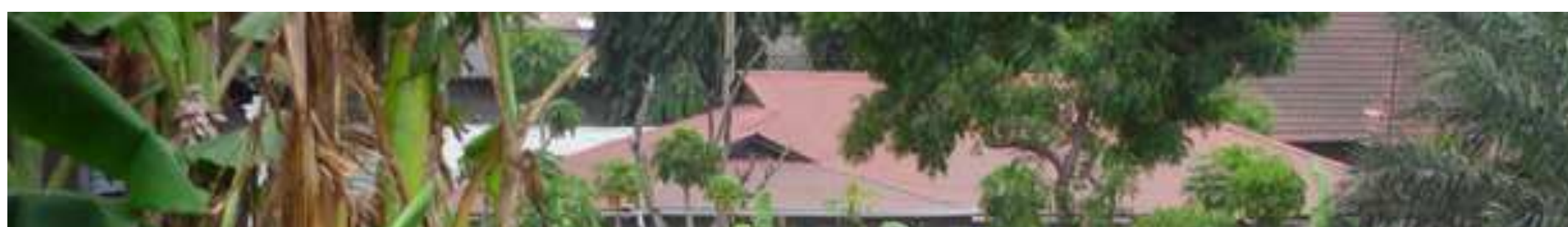

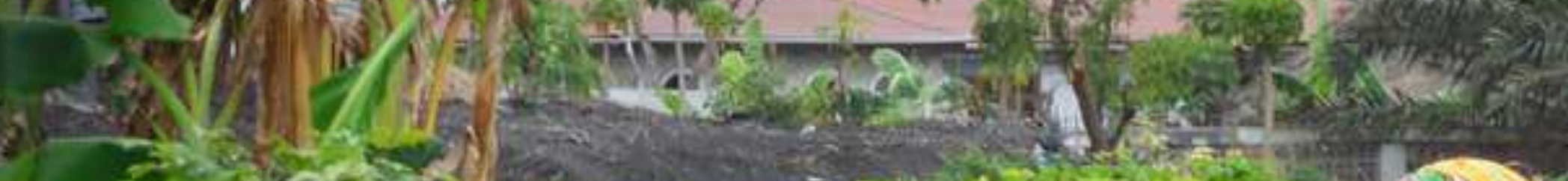

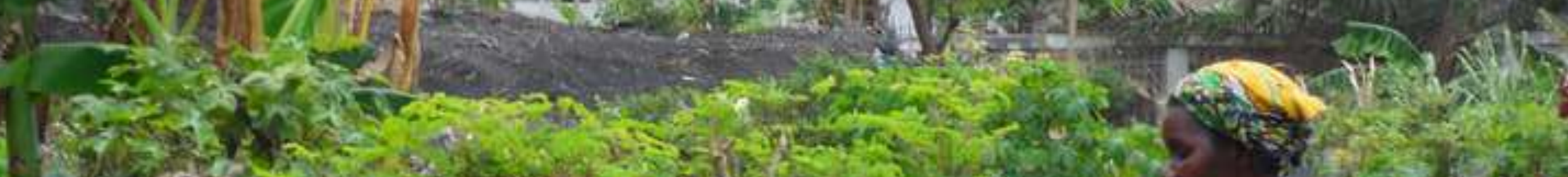

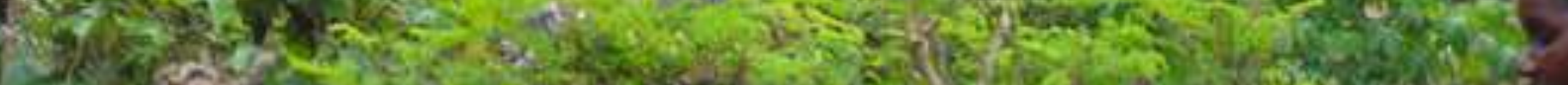

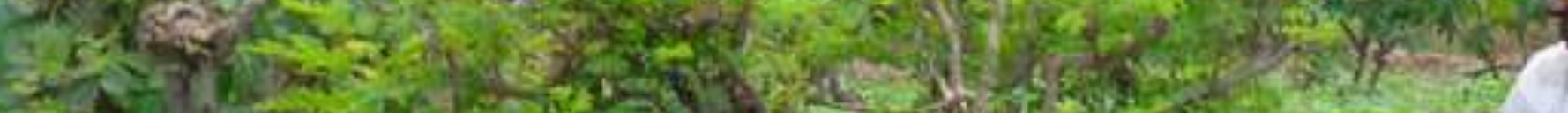
15)

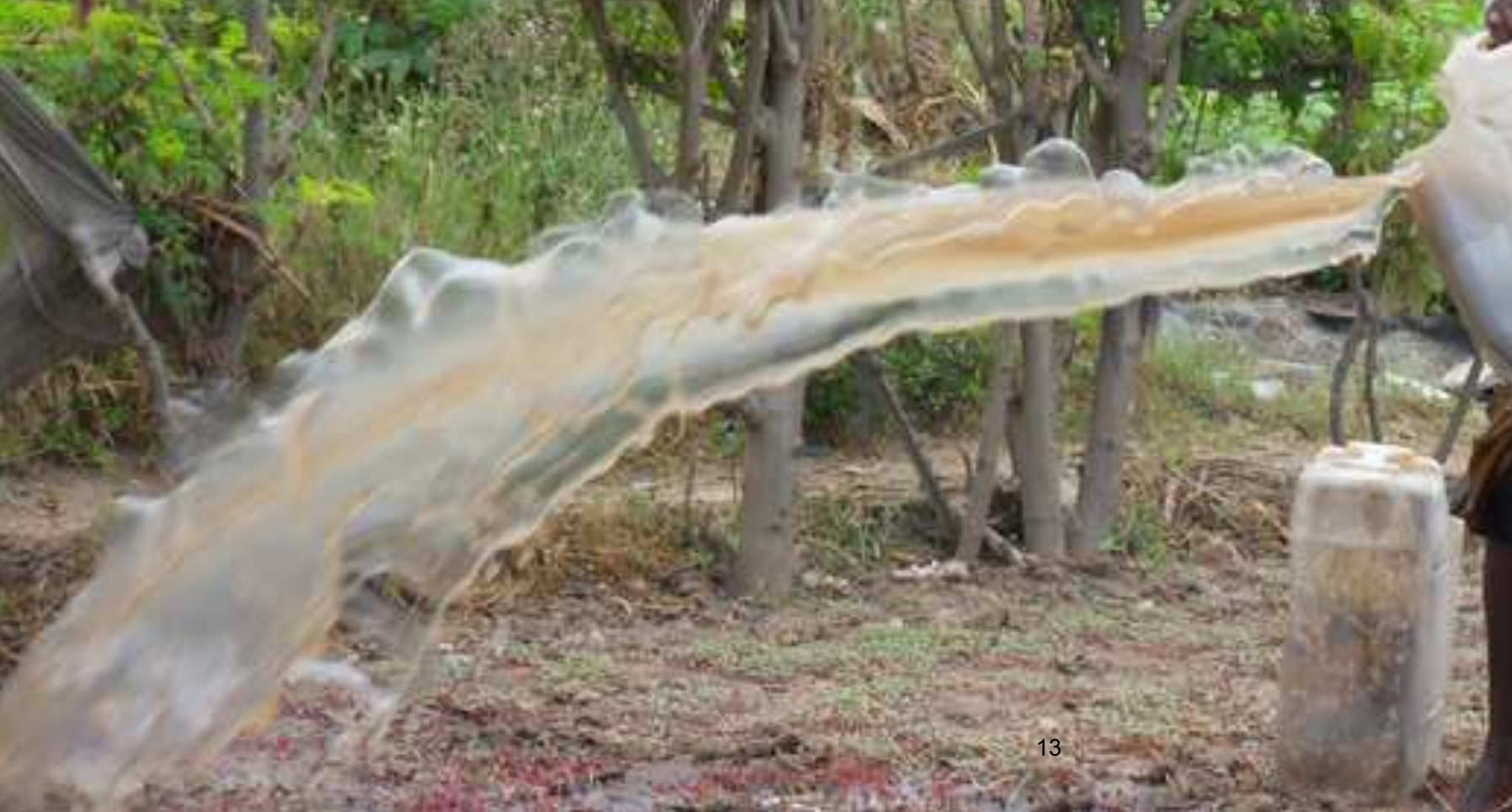

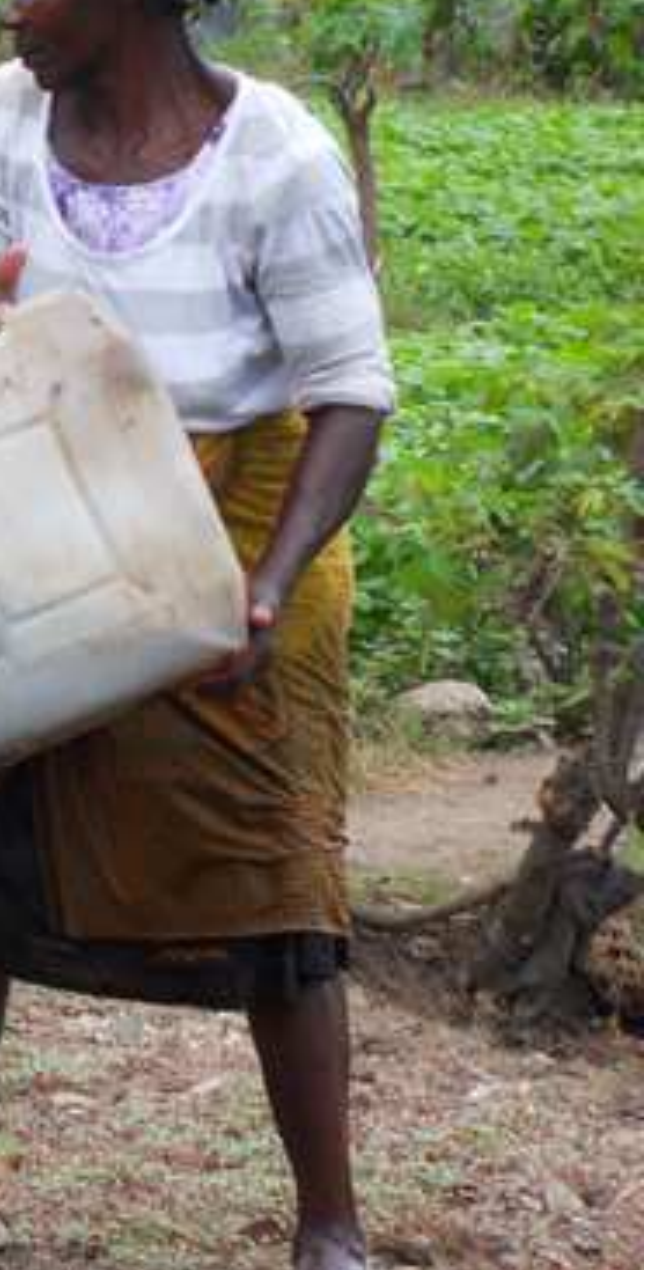


Fig 4: Trucks being loaded with maize in Kibaigwa regional grain market.

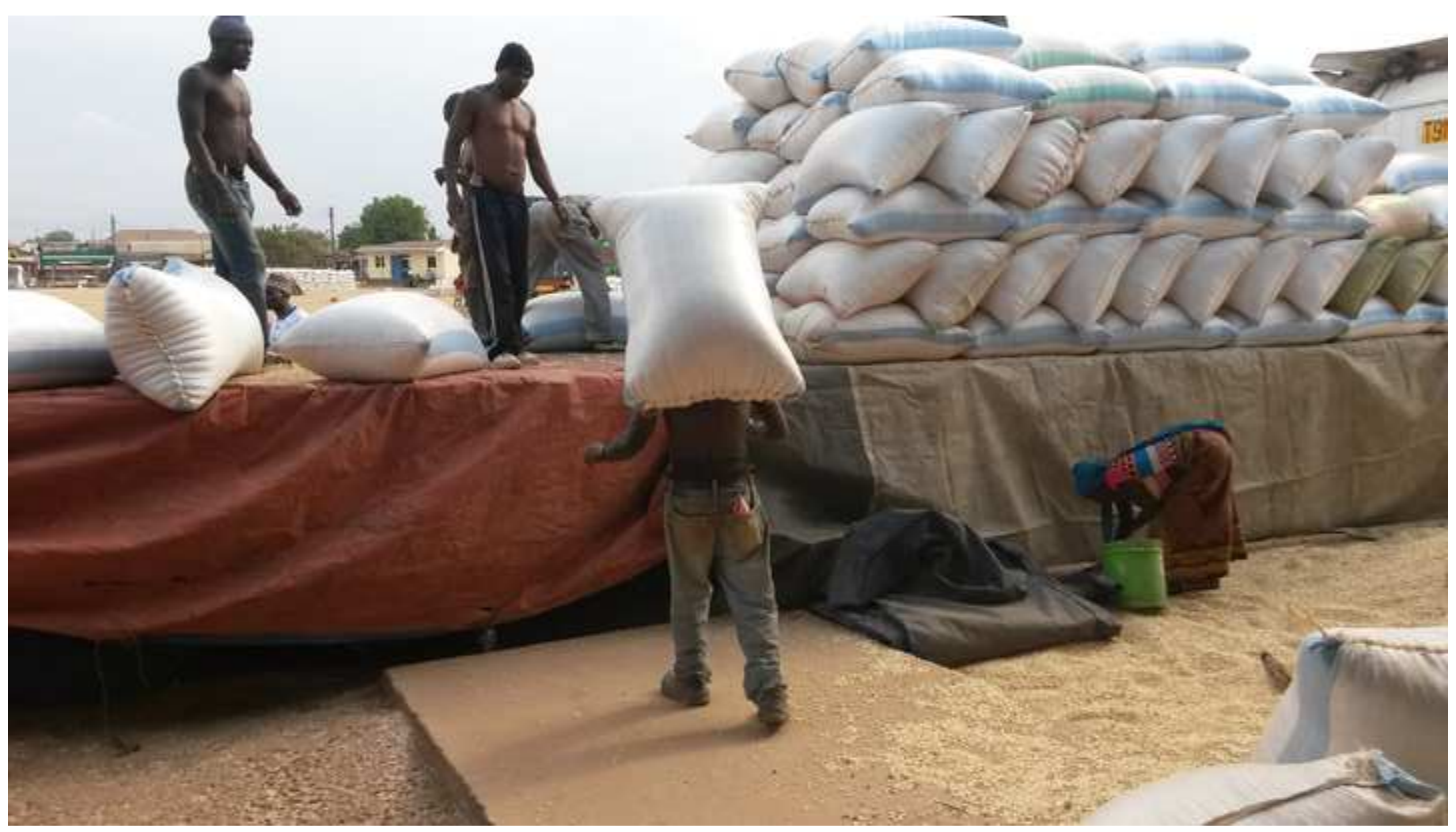


Fig 5: Maize traders sitting together at Kibaigwa in Dodoma Region.

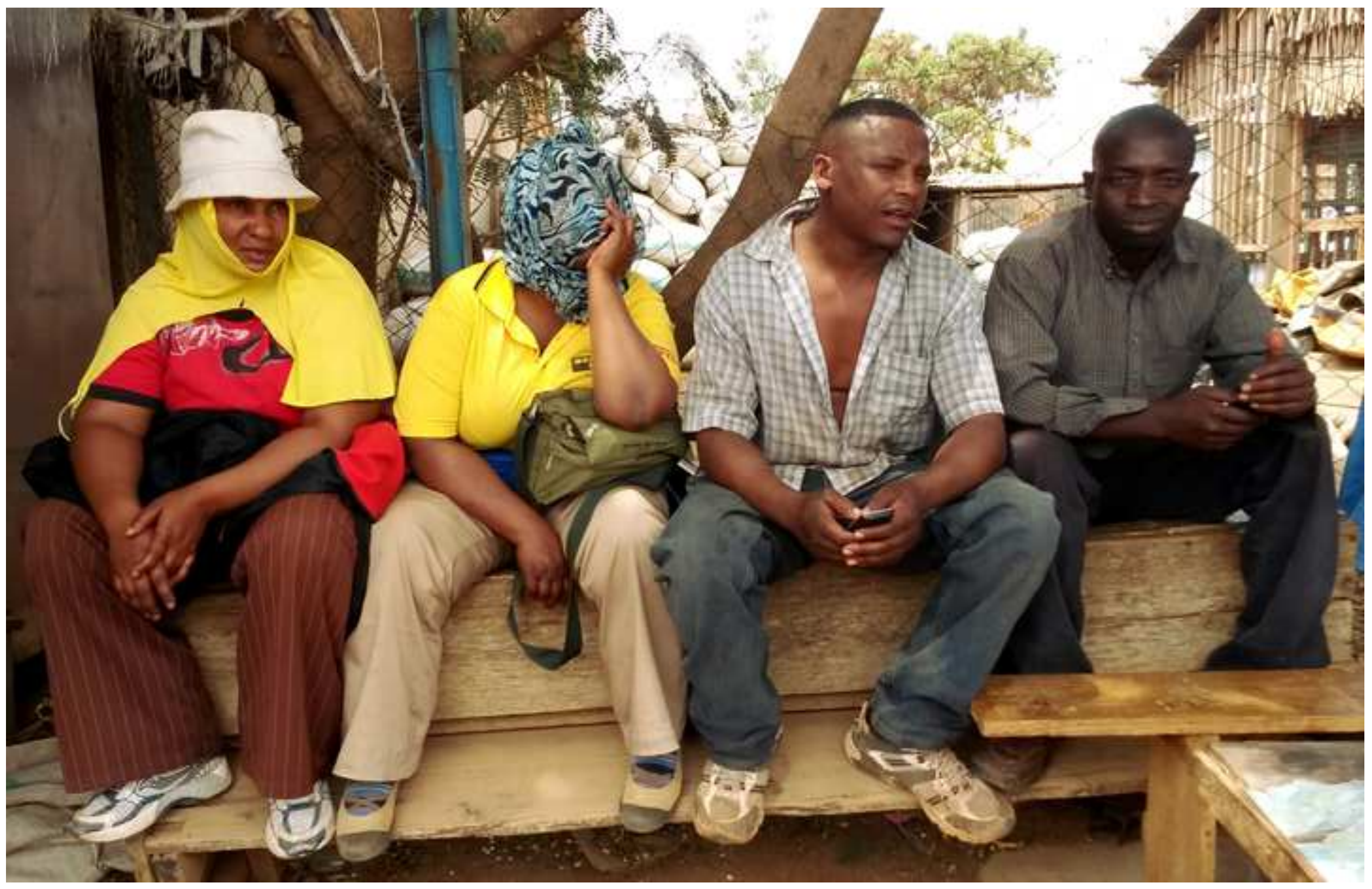


Fig 6: Concluding a deal for maize at Kibaigwa market, Dodoma Region.

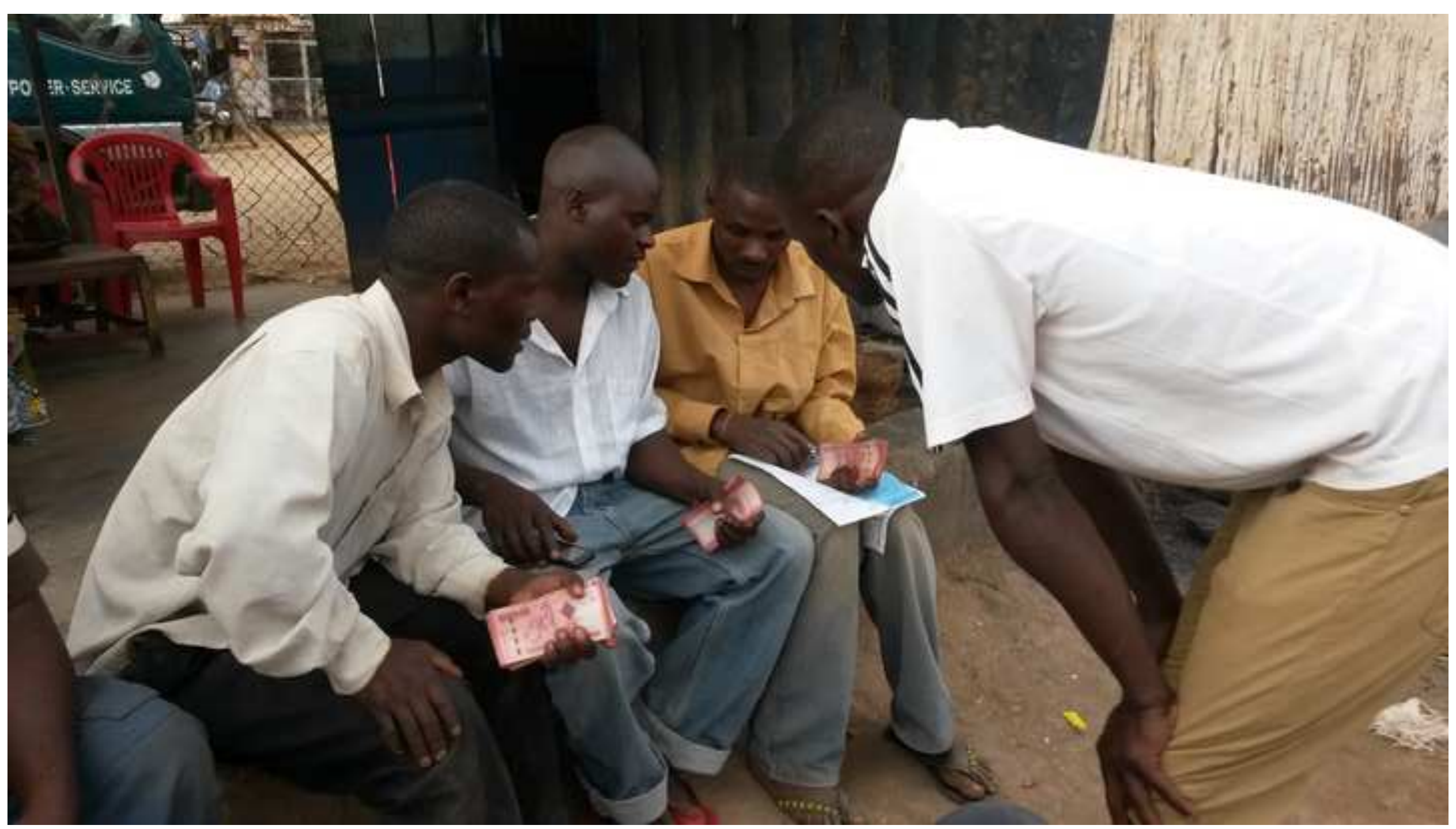

